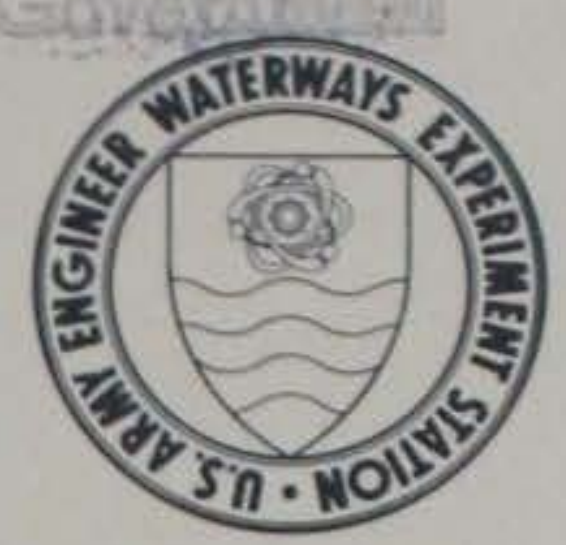

MISCELLANEOUS PAPER GL-82-5

\title{
ASSESSMENT OF THE LIQUEFACTION HAZARDS RESULTING FROM EXPLOSIVE REMOVAL OF THE BIRD'S POINT-NEW MADRID FUZE PLUG LEVEE
}

\author{
by \\ Stephen G. Sanders \\ Geotechnical Laboratory \\ U. S. Army Engineer Waterways Experiment Station \\ P. O. Box 631, Vicksburg, Miss. 39180
}

April 1982

Final Report

Approved For Public Release; Distribution Unlimited

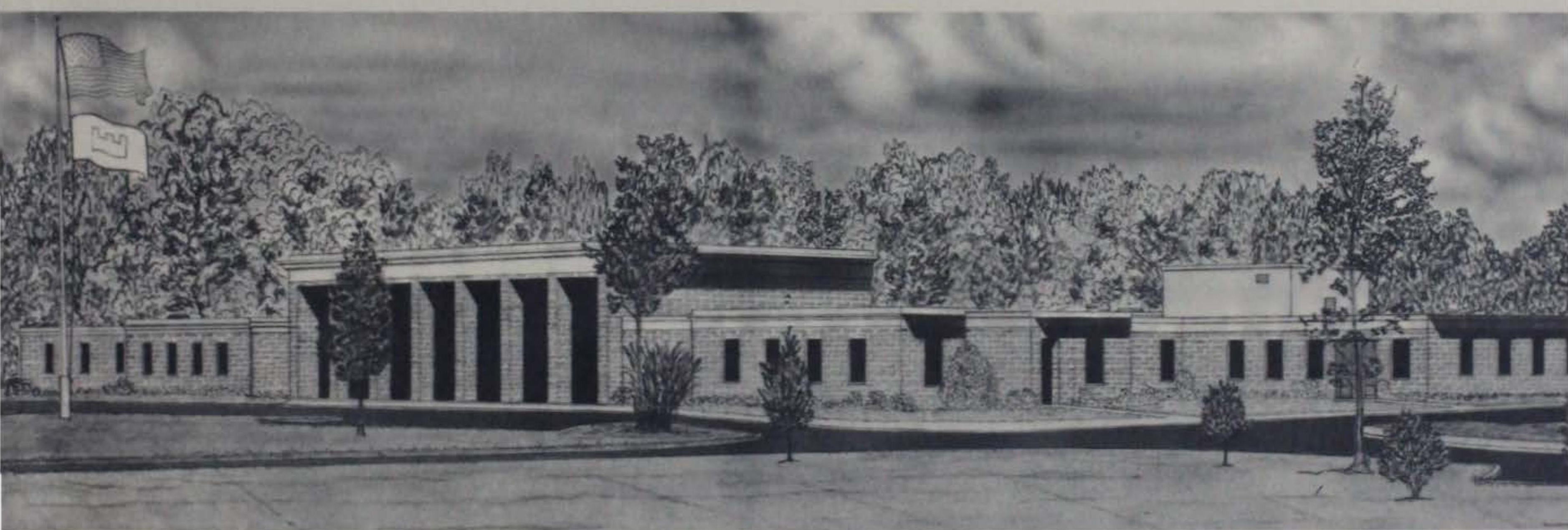

Prepared for U. S. Army Engineer District, Memphis Memphis, Tenn. 38103

Under Intra-Army Order 81-22

LIBRARY BRANCH

TECHNICAL INFORMATION CENTER

US ARUYY EAGINEER WATERWAYS EXPERIMENT STATION

VICKSBURQ, MISSISSIPPI 


\begin{tabular}{|c|c|}
\hline REPORT DOCUMENTATION PAGE & $\begin{array}{c}\text { READ INSTRUCTIONS } \\
\text { BEFORE COMPLETING FORM } \\
\end{array}$ \\
\hline $\begin{array}{l}\begin{array}{l}\text { 1. REPORT NUMBER } \\
\text { Miscellaneous Paper GL-82-5 }\end{array} \\
\text { 2. GOVT ACCESSION NO. } \\
\end{array}$ & 3. RECIPIENT'S CATALOG NUMBER \\
\hline $\begin{array}{l}\text { 4. TITLE (and Subtitie) } \\
\text { ASSESSMENT OF THE LIQUEFACTION HAZARDS RESULTING } \\
\text { FROM EXPLOSIVE REMOVAL OF THE BIRD'S POINT-NEW } \\
\text { MADRID FUZE PLUG LEVEE }\end{array}$ & 6. PERFORMING ORG. REPORT NUMBER \\
\hline $\begin{array}{l}\text { 7. AUTHOR(s) } \\
\text { Stephen G. Sanders }\end{array}$ & 8. CONTRACT OR GRANT NUMBER(s) \\
\hline $\begin{array}{l}\text { 9. PERFORMING ORGANIZATION NAME AND ADDRESS } \\
\text { U. S. Army Engineer Waterways Experiment Station } \\
\text { Geotechnical Laboratory } \\
\text { P. O. Box } 631 \text {, Vicksburg, Miss. } 39180\end{array}$ & $\begin{array}{l}\text { 10. PROGRAM ELEMENT, PROJECT, TASK } \\
\text { AREA \& WORK UNIT NUMBERS } \\
\text { Intra-Army Order } 81-22\end{array}$ \\
\hline $\begin{array}{l}\text { 11. CONTROLLING OFFICE NAME AND ADDRESS } \\
\text { U. S. Army Engineer District, Memphis } \\
668 \text { Clifford Davis Federal Building } \\
\text { Memphis, Tenn. } \quad 38103\end{array}$ & $\begin{array}{l}\text { 12. REPORT DATE } \\
\text { April } 1982 \\
\text { 13. NUMBER OF PAGES } \\
31\end{array}$ \\
\hline 14. MONITORING AGENCY NAME \& ADDRESS(If different from Controlling Office) & $\begin{array}{l}\text { 15. SECURITY CLASS. (of this roport) } \\
\text { UnClaSSIFIEd } \\
\text { 15a. DECLASSIFICATION/DOWNGRADING } \\
\text { SCHEDULE }\end{array}$ \\
\hline
\end{tabular}

Approved for public release; distribution unlimited.

17. DISTRIBUTION STATEMENT (of the abstract entered in Block 20 , if different from Report)

\section{SUPPLEMENTARY NOTES}

Available from National Technical Information Service, 5285 Port Royal Road, Springfield, Va. 22151.

\begin{tabular}{ll}
\hline 19. KEY wORDS (Continuo on reverse side if necessary and identify by block number) \\
Attenuation & Liquefaction \\
Explosive effects & Particle velocity \\
Fuze plug & Propagate \\
Ground motion & Slurry explosives
\end{tabular}

20. ABSTAACT (Continue an reverse sidin if necesaary and tdentify by block number)

Under certain extreme circumstances emergency flood procedures call for the creation of two large crevasses in the Bird's Point-New Madrid fuze plug levee on the Missouri side of the Mississippi River below Cairo, I11.

In this situation, slurry explosives will be used to create an 11,370- and a $6,000-\mathrm{ft}$ breach in the levee system. Potential liquefaction hazards to the surrounding population centers, the manline setback levee, and the new end

(Continued) 


\section{Abstract (Cont'd):}

sections of the forward levee (which will exist if the fuze plugs are removed) were assessed.

Three major problems had to be overcome: (a) the scarcity of borehole data below $15 \mathrm{ft}$ in the area of concern, (b) the scarcity of data bearing on the investigation of blast-induced liquefaction, and (c) the inability of conventional methods to predict explosion effects such as ground motion. The last problem stated is due to the unusual geometry of the explosion. A data base from row charge experiments in soil was used in the assessment of the liquefaction hazards of this project.

As a result of this study, it is concluded that:

a. No liquefaction should be expected at distances greater than $1275 \mathrm{ft}$ from the 11,370-ft levee section. Therefore, the setback levee faces no liquefaction hazard from the explosion.

b. There will be no liquefaction occurring within Wickliffe, KY, or Cairo, IL, which are both well beyond the 1275-ft liquefaction hazard range.

c. No liquefaction should be caused by the explosive removal of the $6000-\mathrm{ft}$ levee section.

d. Liquefaction might occur in the foundation of the $11,370-\mathrm{ft}$ fuze plug and at the newly exposed end sections in the forward levee that will exist once the fuze plug is removed. The liquefaction could not extend to more than about $1000 \mathrm{ft}$ from the ends of the explosive line. 
This report presents an assessment of the liquefaction hazards that would be created by explosives used to breach the Bird's Point-New Madrid fuze plug levee on the Mississippi River below Cairo, IL. This assessment was conducted for the Memphis District, CE, under Intra-Army Order 81-22, dated 2 July 1981.

LT Stephen G. Sanders of the Earthquake Engineering and Geophysics Division (EE\&GD), Geotechnical Laboratory (GL), conducted the study and authored this report. Special thanks are extended to Dr. Paul F. Hadala, Assistant Chief, GL, whose help in determining a possible liquefaction particle velocity threshold was a critical part of this report.

Direct supervision was provided by Mr. R. F. Ballard, Jr., EE\&GD. General supervision was provided by Drs. A. G. Franklin, Chief, EE\&GD, and W. F. Marcuson III, Chief, GL.

COL T. C. Creel, CE, was the Commander and Director of the US Army Engineer Waterways Experiment Station during the preparation of this report. Mr. F. R. Brown was Technical Director. 
PREFACE . . . . . . . . . . . . . . . . . . . .

CONVERSION FACTORS, US CUSTOMARY TO METRIC (SI)

UNITS OF MEASUREMENT . . . . . . . . . . . . . . . . . . . 3

PART I: INTRODUCTION . . . . . . . . . . . . . . . . . 4

Background . . . . . . . . . . . . . . . . . . 4

Problem Statement .................. . 4

PART II: APPROACH ..................... . . . 8

General Considerations . . . . . . . . . . . . . 8

Specific Approach . . . . . . . . . . . . . . . 9

PART III: DETERMINATION OF LIQUEFACTION LIMITS . . . . . . . . . 13

Liquefaction Potential Velocity Threshold . . . . . . . 13

Ground Motions at Project Site . . . . . . . . . . . . . 14

PART IV: SUMMARY AND CONCLUSIONS . . . . . . . . . . . . . . 21

Limits of Liquefaction Damage . . . . . . . . . . . 21

Effects at Mainline Setback Levee . . . . . . . . . . . 21

Effects at Wickliffe, KY . . . . . . . . . . . . . 21

Effects at Cairo, IL .. . . . . . . . . . . . . 23

Effects on the Fuze Plug Levee... . . . . . . . . . . 23

Conclusions . . . . . . . . . . . . . . . . . 24

REFERENCES . . . . . . . . . . . . . . . . . . . 25

APPENDIX A: REVIEW OF CONCLUSIONS BY PROFESSOR H. B. SEED . . . Al 
US customary units of measurement used in this report can be converted to metric (SI) units as follows:

Multiply

inches

feet

inches per second

pounds (mass)

tons (mass)

miles

\begin{tabular}{l} 
By \\
\hline 2.54 \\
0.3048 \\
2.54 \\
0.4535924 \\
0.0011023 \\
1.609344
\end{tabular}

To Obtain

centimetres

metres

centimetres per second

kilograms

kilograms

kilometres 


\section{ASSESSMENT OF THE LIQUEFACTION HAZARD RESULTING FROM \\ EXPLOSIVE REMOVAL OF THE BIRD'S POINT-NEW MADRID FUZE PLUG LEVEE}

\section{PART I: INTRODUCTION}

\section{Background}

1. The December 1979 draft of the Emergency Operations Plan (EOP) by the US Army Engineer District, Memphis (1979) describes in detail the procedure for explosively creating breaches in the Bird's Point-New Madrid fuze plug levee on the Mississippi River below Cairo, IL. (Figure 1). Creation of two large crevasses would use an estimated 128 tons* of explosive slurry (ES) with 1 ton of booster explosives and 67.5 tons of ES with 0.5 tons of booster explosives along 11,370 - and 6,000-ft sections of the levee system, respectively. The question was raised as to whether or not this amount of explosive force would cause liquefaction hazards to structures in the area. The objective of this report is to assess whether these hazards exist.

\section{Problem Statement}

2. The EOP describes in detail the operations including explosive amounts and configurations to be used to create the crevasses. Two crevasses are planned: (a) No. 1 is $11,370 \mathrm{ft}$ long, and (b) No. 2 is 6,000 ft long. The explosive plan is nearly the same for each crevasse; three parallel lines of explosive charges spaced $12 \mathrm{ft}$ apart, running the length of each crevasse. Holes, each containing $120 \mathrm{lb}$ of aluminized slurry explosive and $1 \mathrm{lb}$ of booster explosive, will be placed at 16-ft intervals along each line, providing about $22.7 \mathrm{lb}$ of explosive per linear foot of crevasse (Figure 2). Thus, approximately 128 tons of ES with 1 ton of booster explosive will be used on crevasse No. 1, and about 67.5 tons of ES with 0.5 tons of booster explosive is planned for crevasse No. 2. Demolition of the crevasses, described above, will not be simultaneous.

* A table for converting US customary to metric (SI) units of measurement is given on page 3 . 


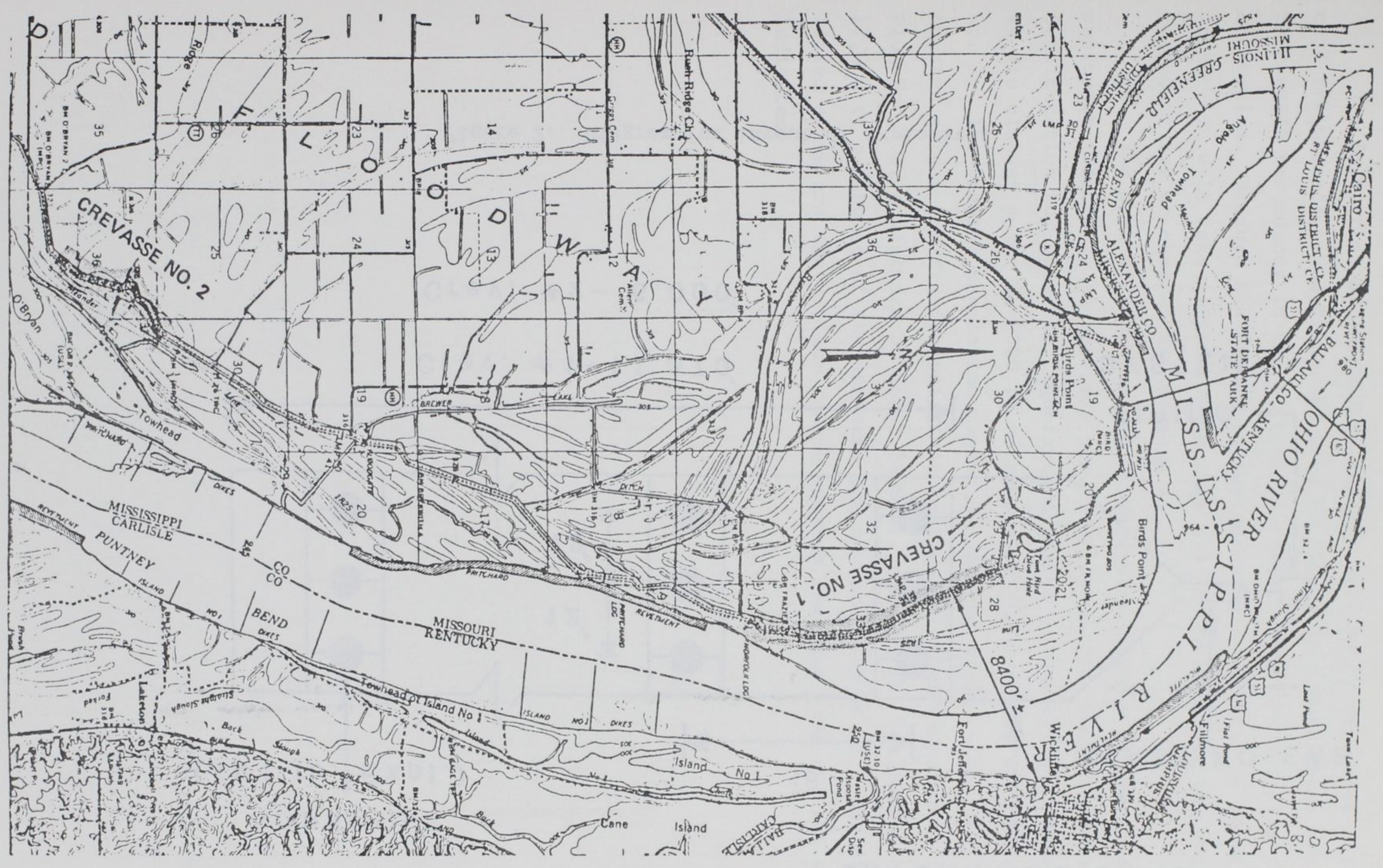

Figure 1. Vicinity map, Birds Point - New Madrid Floodway. 


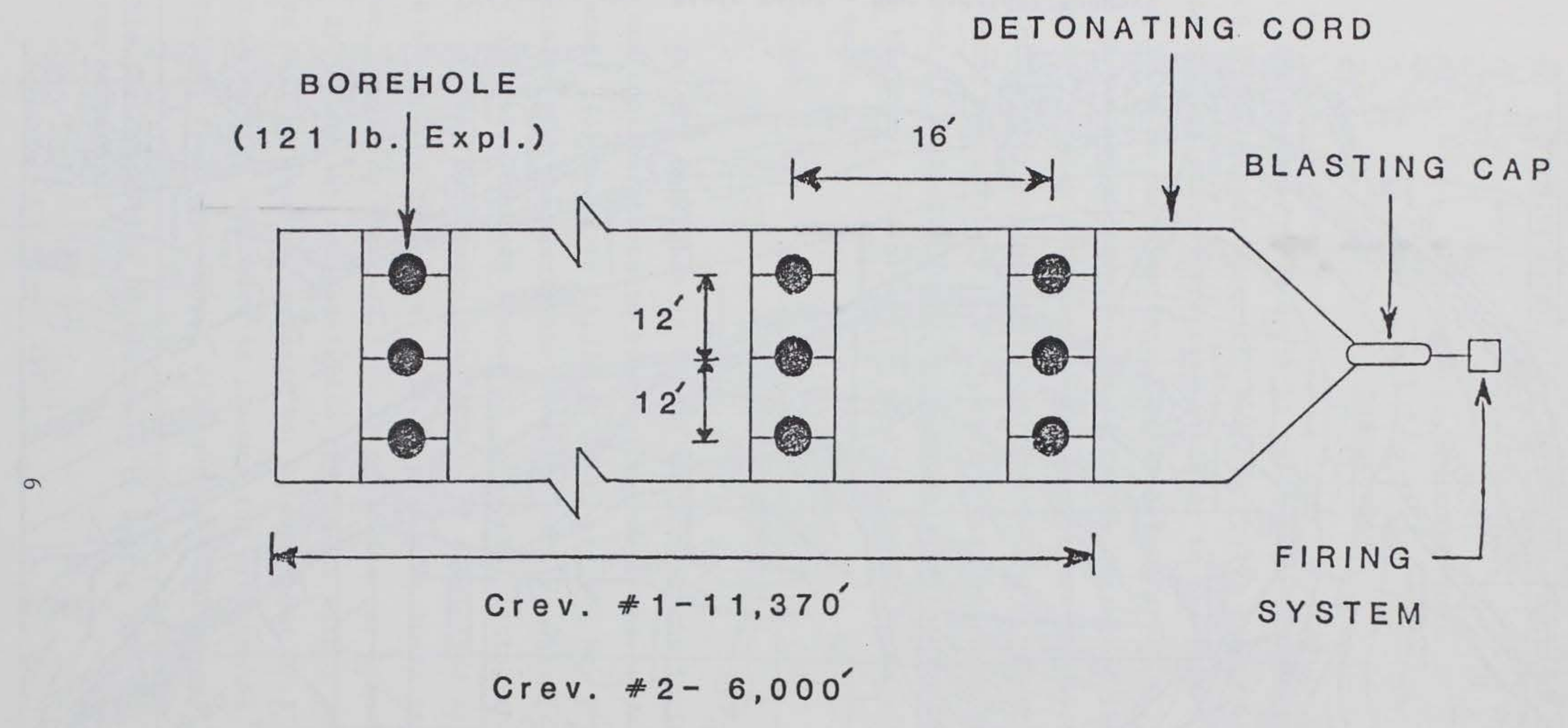

Figure 2. Diagram for layout of explosives 
3. Initiation of individual charges will be by explosive detonation cord (Primacord). The Primacord will be placed in a loop above the ground to provide redundancy in the initiation chain, therefore ensuring total detonation. Because the Primacord detonates at a velocity of about 22,000 $\mathrm{ft} / \mathrm{sec}$, it will take slightly more than $0.5 \mathrm{sec}$ to detonate the entire $11,370-\mathrm{ft}$ row of charges in crevasse No. 1 .

4. The area surrounding the levee system and the floodway to the southwest (Figure 1) is sparsely populated farmland. One structure under consideration for possible liquefaction hazard is the setback levee, which at its closest point is $9500 \mathrm{ft}$ northwest of the northern end of fuze plug No. 1. The nearest population center of concern is Wickliffe, KY, which is located across the Mississippi River northeast of the midpoint of fuze plug No. 1 at a distance of about $8400 \mathrm{ft}$. Cairo, IL, is located about $17,000 \mathrm{ft}$ northwest of the northern end of fuze plug No. 1 . The distances listed above are the minimum ranges between the fuze plug and the structures indicated. 


\section{Genera1 Considerations}

5. Because of the complexity of the explosive source (multiple charges in a row with nonsimultaneous detonations), there are no known methods or precedents to calculate the long-range shock effects from first principle approaches. Data collected and analyzed by Drake and Ingram (1981) were used as the basis for ground motion estimates.

6. Primary factors influencing the strength of ground shock, and consequent liquefaction potential, from buried cratering row charges include: (a) soil properties, (b) depth of burial, (c) local geology, and (d) geometric relationships of the target point to the charge.

a. Soil properties. In general, peak particle velocity (which is generally recognized as the most significant descriptor of damage potential) is lower for explosives in soil than in rock. Wet soils can produce higher accelerations than dry and generally exhibit higher particle velocities. Vibration periods of ground motions in soils are much longer than in rock. Ground motion frequencies are roughly proportional to the shear wave velocity in the geologic medium.

b. Depth of burial. Ground shock increases rapidly with increase in depth of burial until the explosion is fully contained (no crater). In the case of intended cratering, less direct induced ground motion occurs than witk a fully contained burst.

c. Local geology. High-contrast geologic interfaces between the explosion source and the structure influence the frequency of the ground motion. Shallow depths to rock will produce higher frequency motions, while deep rock layers will result in low frequency particle motions. Since the area in question has a relatively deep rock layer (greater than $100 \mathrm{ft}$ ), the resulting particle motions will be low in frequency.

d. Geometric relationships. Geometrical spreading of the ground motion accounts for much of the attenuation of peak particle velocity and acceleration with distance from the explosion. Energy from a concentrated charge is distributed initially on the surface of a sphere, while from a line charge is distributed initially on the surface of a cylinder. For the line charge, the energy must be expressed as the charge weight per unit length, 
$w$, of the line. Thus, near a long row charge (within one charge length), the amplitude of the ground motion depends on the linear charge density, w, and not the total charge weight, W. In this region, attenuation of effects is much less rapid than for point source explosions and should scale proportional to $(w)^{1 / 2}$. At distances greater than the length of a line charge, propagation becomes more and more spherical and the total charge weight, $W$, can be used to evaluate the potential hazards. Effects in this region scale proportional to $(\mathrm{W})^{1 / 3}$. The total length of the fuze plug will be considered to be the length of the line charge for purposes of determining the worst case.

\section{Specific Approach}

7. During the period 11-15 January 1982, a data search was conducted in the Memphis District files. It was found that very few borings were taken in the areas of interest. Out of approximately 120 borings in the general area, only 14 were in the areas of interest. The 14 are located as follows; 7 along the nearest sections of the setback levee, 4 in the vicinity of fuze plug No. 2, and 3 in the vicinity of fuze plug No. 1. The scarcity of borehole data at depths below $15 \mathrm{ft}$ requires an ad hoc approach in determining whether liquefaction potential is of concern. This approach is simply:

a. Determine a possible liquefaction particle velocity threshold

b. Determine at what maximum range from the explosive charge this particle velocity could be expected.

c. Determine whether the structures of interest are within this

\section{range.}

In this approach it is assumed that loose wet sand, a material very susceptible to liquefaction, exists everywhere. This is, of course, not the case and is a very conservative assumption.

8. The first step was based on reports by Krinitzsky and Chang (1977) and Kuribayashi and Tatsuoka (1975). The second step was based on ground motion studies for this project by Drake and Ingram (1981). The third step was accomplished by a study of the US Geological Survey maps of the area of interest. 


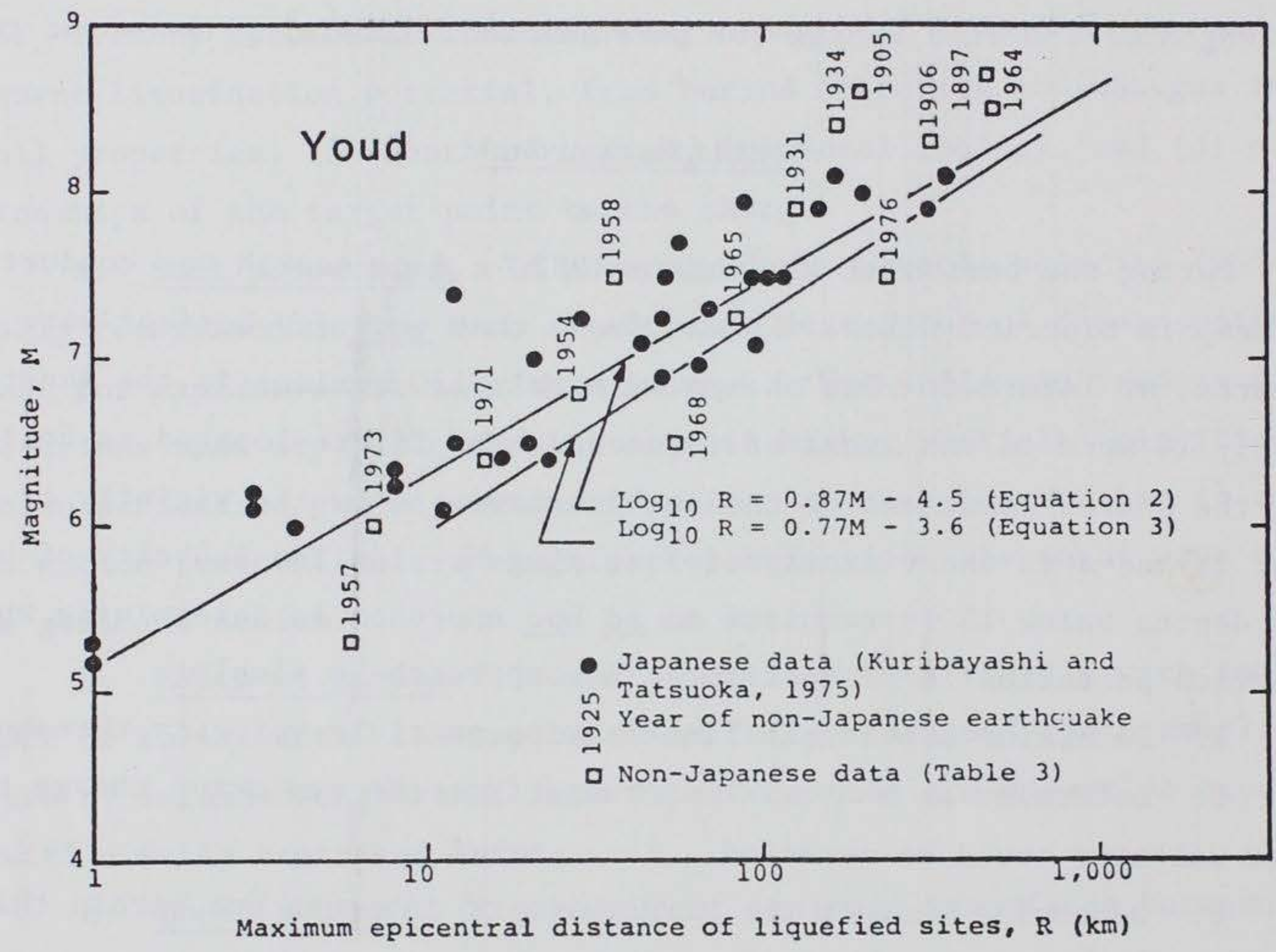

Figure 3. Relationship between the maximum epicentral distance of liquefied sites $\mathrm{R}$ and Magnitude $\mathrm{M}$ with added non-Japanese data 


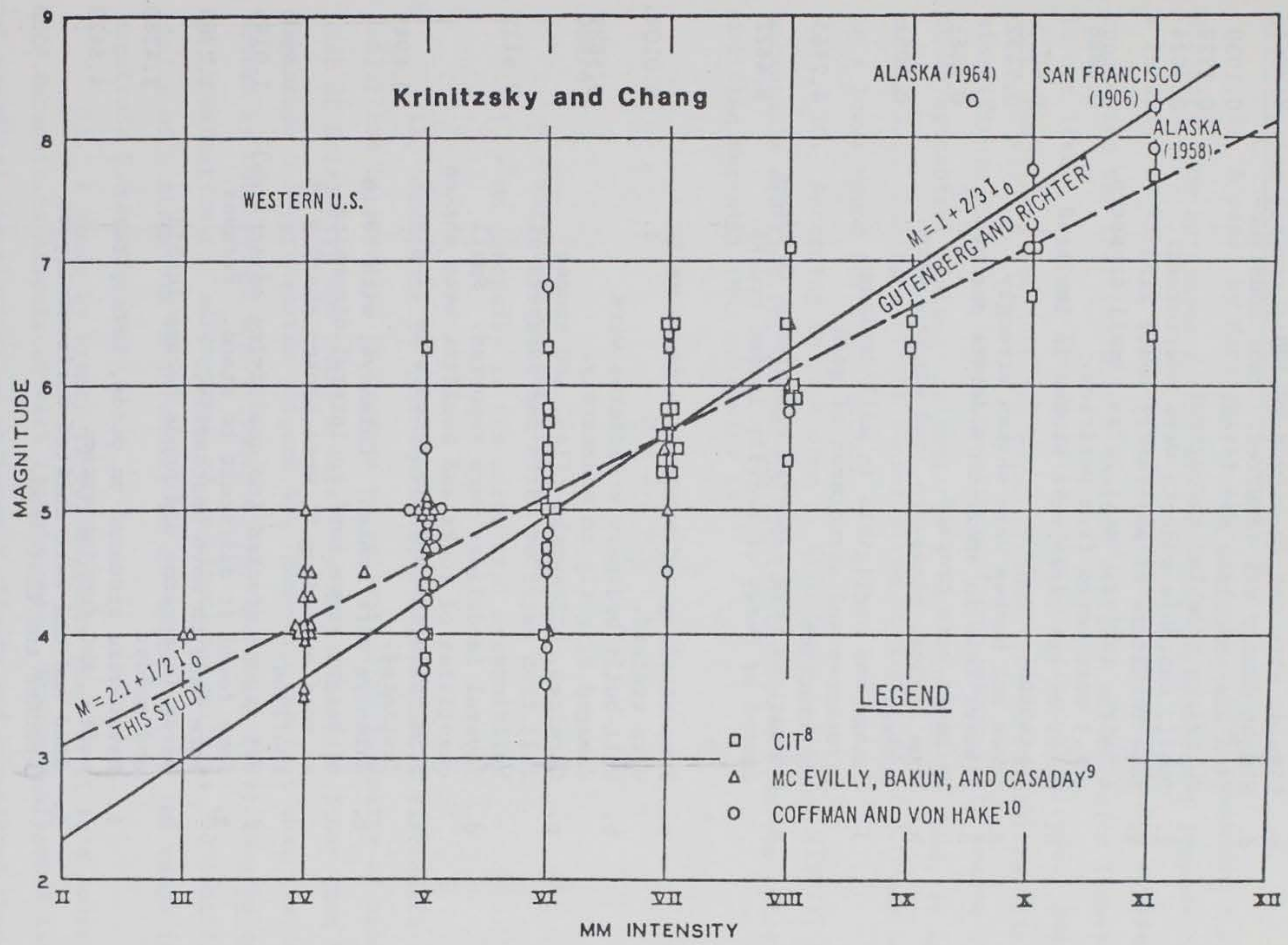

Figure 4. Relation between earthquake magnitude and intensity 
a. Liquids were spilled from containers.

b. Roaring sounds were reported.

c. Liquids were set in strong motion.

d. Slight damage was incurred. Poor construction was sometimes specified.

0.1030

e. Buildings trembled throughout.

f. Small, unstable objects were overturned.

g. Some furniture of moderately heavy kind (chairs, tables, small sofas, small dressers, etc.) were moved from position.

h. Water or gas pipes were broken in isolated instances.

i. Trees and bushes were shaken strongly.

j. Plaster fell in smal1-to-moderate amounts. Chimneys were cracked.

k. Some dishes, glassware, and windows were broken.

1. Damage was negligible in well-designed structures and structures of good construction.

m. Vibrations were reported comparable to those caused by heavy of heavily loaded trucks.

a. Free-standing and exterior masonry walls were cracked.

b. Well-built ordinary structures were damaged slightly to moderately.

c. Cornices, brickwork, tiles, and stones fell from exterior walls and parapets of buildings.

d. Several landslides were reported. Small quantities of rocks and boulders were shaken from hillsides and embankments in single instances.

e. Chimneys were broken. Chimneys, with ratio of height above roof to lateral dimension at roof exceeding 5, were broken sharply at roofline.

f. Wet ground cracked (no qualifying adjectives).

g. Some found it difficult to stand. Persons were made to move unsteadily.

h. Water in streams and ponds became turbid and muddy.

i. Waves were produced on ponds, lakes, reservoirs, and running water.

j. Sand and mud were shifted horizontally on beaches and flat land. 


\section{Liquefaction potential velocity threshold}

9. A paper by Kuribayashi and Tatsuoka (1975) contained a plot of distance from epicenter to the most distant occurrence of liquefaction as a function of Richter magnitude for the Japanese earthquakes studied. The conclusion was that there is a maximum distance beyond which liquefaction is not likely to occur for an earthquake of a given magnitude. Additional data, compiled throughout the world by Youd (1977), reinforces this conclusion (Figure 3). The lowest magnitude of an earthquake to induce liquefaction at an epicentral distance as small as $1 \mathrm{~km}$, according to Youd, is approximately 5.2. Adding a slight conservatism, a magnitude of 5.0 can be taken as a lower bound for liquefaction.

10. According to work done by Krinitzsky and Chang (1977), an acceptable equation for estimating Richter magnitude from the epicentral Modified Mercalli (MM) intensity is:

$$
M=2.1+\frac{1}{2} I_{0}
$$

where

$$
\begin{aligned}
M & =\text { magnitude on the Richter scale } \\
I_{0} & =M M \text { intensity in the epicentral area }
\end{aligned}
$$

11. According to this equation, a magnitude 5.0 earthquake (Richter scale) can be expected to produce an epicentral MM intensity of about VI. Most of Krinitzsky and Chang's data show MM intensities lower than VI for magnitude 5.0 earthquakes (Figure 4). However, the fact that the data presented by Kuribayashi and Tatsuoka (1975) and Youd (1977) show no occurrences of liquefaction for earthquakes of magnitude as small as 5.0 justifies the choice of a threshold MM intensity in the upper part of the range for magnitude 5.0 earthquakes.

12. A study by Brazee (1980) suggests that MM VI is a lower bound for intensities associated with liquefaction. Brazee analyzed a large body of anecdotal descriptions of earthquake effects and correlated them statistically with the MM intensity scale. An except, showing effects associated with 
intensities of VI and VII is shown in Figure 5. The quantity $\sigma$ in Figure 5 is a measure of the significance of the occurrence as an indicator of intensity. Values less than 1.0 correspond to very important indicators, while values greater than 3.0 correspond to occurrences that are of little use in assigning intensities. Brazee observes that liquefaction, as such, is seldom reported. Nevertheless, associated with MM VII are observations of ground instability ("landslides," "wet ground cracked," "sand and mud were shifted horizontally") some of which suggest liquefaction. No such observations, or others that plausibly suggest liquefaction, are associated with MM VI. These observations strongly suggest that the lowest MM intensity associated with liquefaction is somewhat greater than VI but is probably not greater than VII.

13. Krinitzsky and Chang compare observed particle acceleraation and velocity with MM intensities (Figure 6 and 7). Data was collected and classified as belonging to the far field or the near field. Data representing the near field was chosen for use in this study.

14. From Figures 6 and 7 , a mean particle acceleration of approximately $0.12 \mathrm{~g}$ and a mean particle velocity of approximately $10 \mathrm{~cm} / \mathrm{sec}$ were chosen, based on the median of the observed data. Because the data available indicate that liquefaction does not occur where the MM intensity is classified as low as VI, the choice of median values (the 50 th percentile) for peak acceleration and velocity is a conservative one. The conclusion drawn is that sinçe the lower magnitude to induce liquefaction, according to the data compiled by Youd (1977), is greater than 5.0, a peak particle velocity greater than $10 \mathrm{~cm} / \mathrm{sec}$ would be necessary (with a peak acceleration greater than $0.12 \mathrm{~g}$ ) to induce liquefaction. An additional point of interest is that the average duration of a 5.0 earthquake, for a soil site in the near field, is approximately $5.0 \mathrm{sec}$ (acceleration $\geq 0.05 \mathrm{~g}$ ). The duration of ground shaking in a large chemical explosion is much smaller. Since liquefaction potential increases with duration of ground shaking, the use of earthquake force criteria is considered very conservative for chemical explosions.

Ground motions at project site

15. Ground motion data from row charges in soil are limited to testing conducted by WES for the MEACE program and row charge tests at the WES Big Black Test Site. These data were compiled by Murrell (1977). Ground motions 


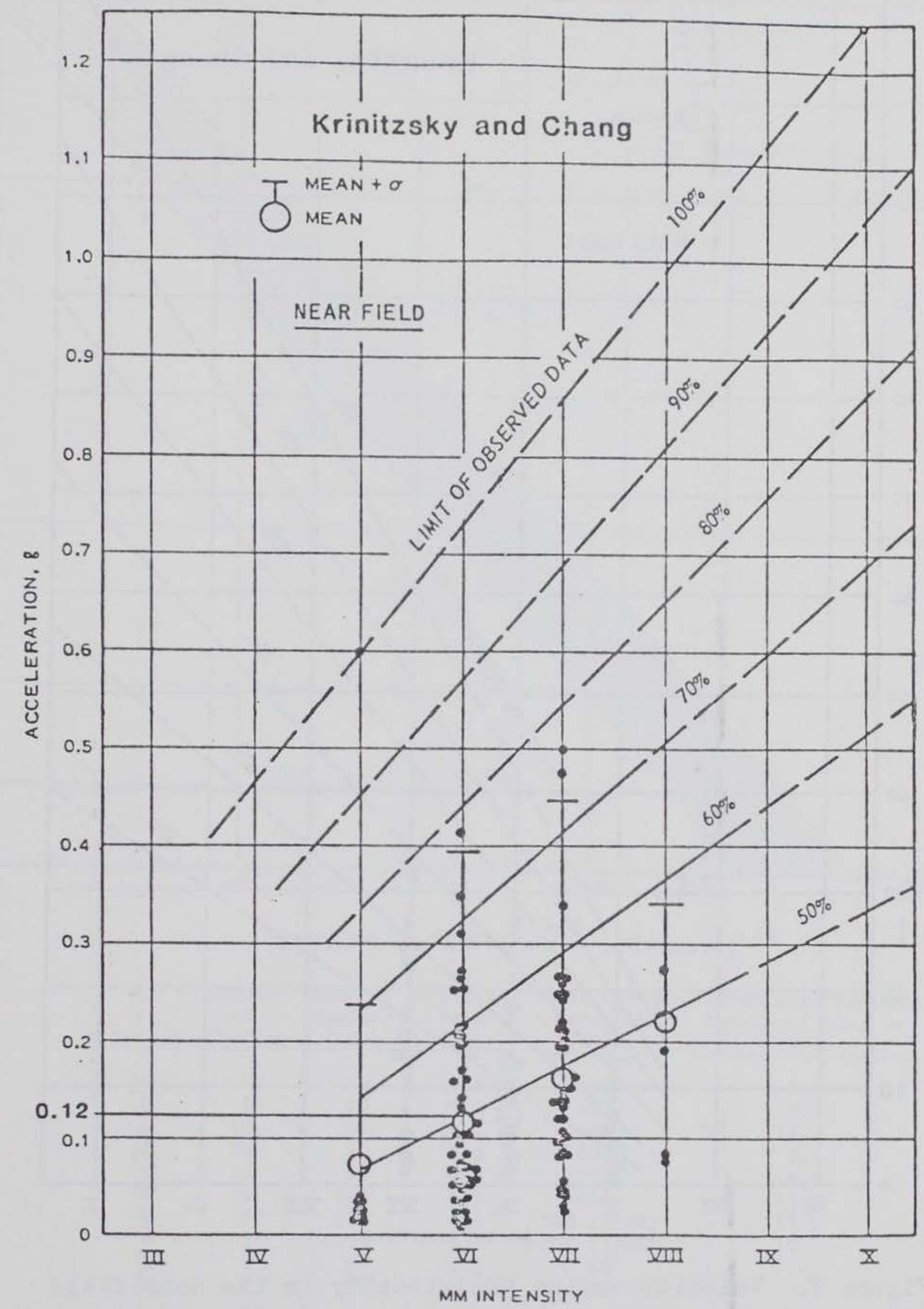

Figure 6. Acceleration versus $M$ M intensity in the near field (10 percent increments between the mean (50\%) and the limit of observec data (100\%) 


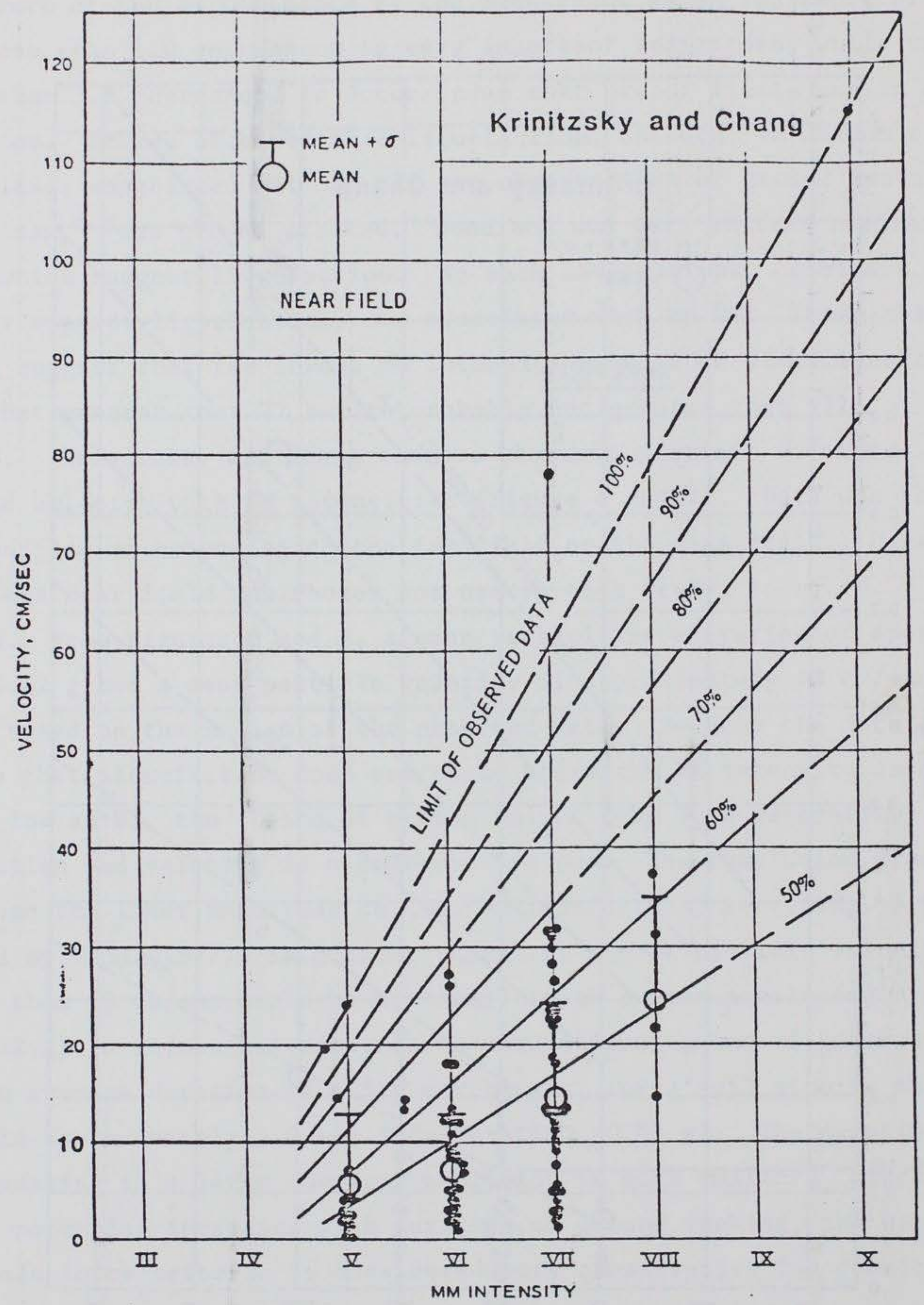

Figure 7. Velocity versus MM intensity in the near field (10 percent increments between the mean (50\%) and the limit of observed data $(100 \%)$ ) 


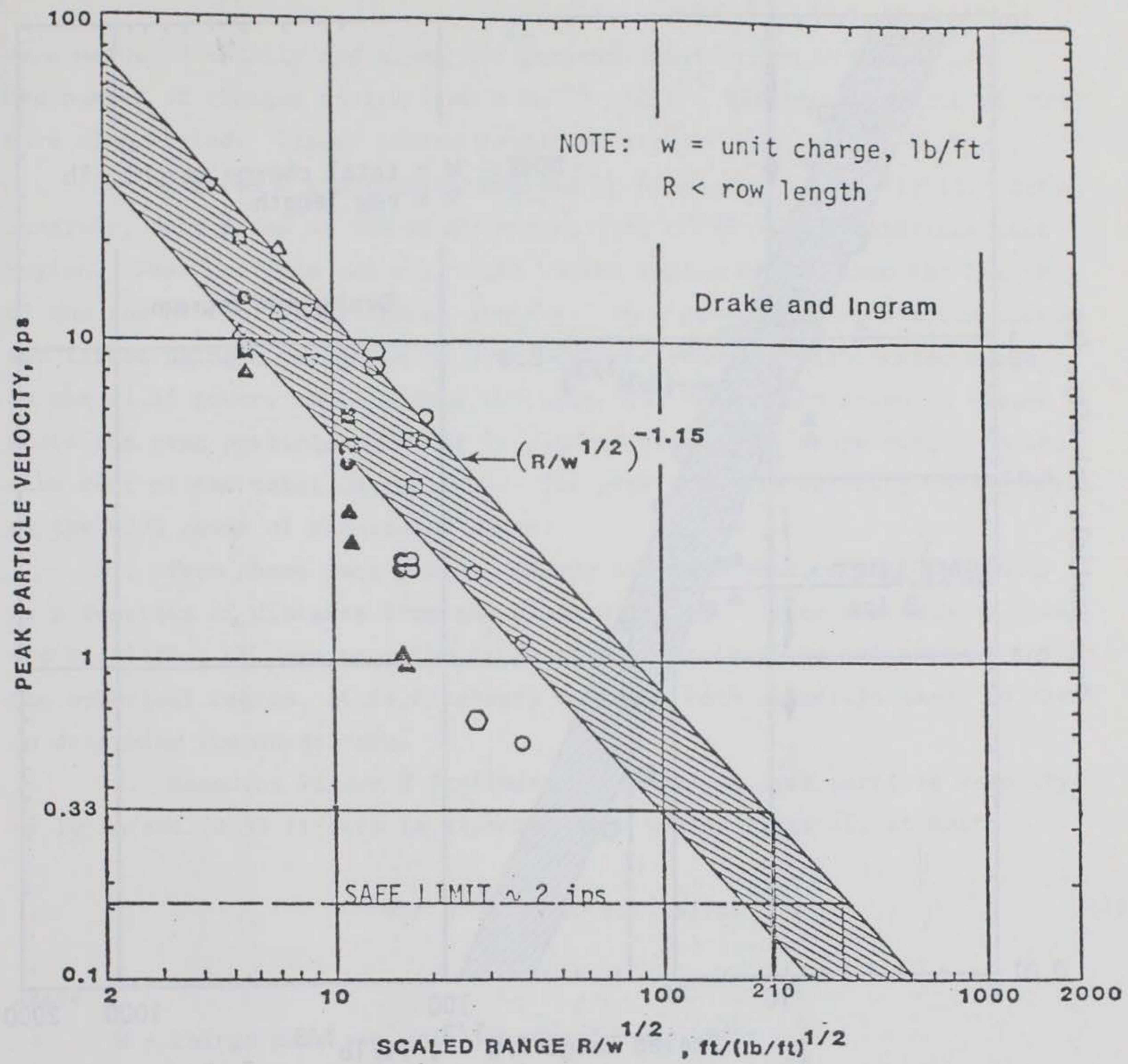

\begin{tabular}{|c|c|c|c|c|c|}
\hline Symbol & $\begin{array}{c}\text { Number } \\
\text { of } \\
\text { Charges }\end{array}$ & $\begin{array}{c}\text { Mass of } \\
\text { Charges } \\
(1 \mathrm{bs}) \\
\end{array}$ & $\begin{array}{l}\text { Depth of } \\
\text { Burst } \\
\text { (ft) } \\
\end{array}$ & $\begin{array}{c}\text { Total Charge } \\
\text { Mass, W } \\
\text { (1bs) }\end{array}$ & $\begin{array}{c}\text { Charge Mass Per } \\
\text { Length of row. } \\
(1 \mathrm{~b} / \mathrm{ft}\end{array}$ \\
\hline 0 & 6 & 60 & 6.5 & 360 & 4.0 \\
\hline 口 & 8 & 60 & 9.4 & 480 & 8.2 \\
\hline$\Delta$ & 10 & 60 & 11.1 & 600 & 11.3 \\
\hline 0 & 10 & 60 & 8.5 & 600 & 7.4 \\
\hline$\nabla$ & 12 & 60 & 10.8 & 720 & 18.0 \\
\hline - & 5 & 170 & 8.5 & 850 & 12.8 \\
\hline 目 & $5^{*}$ & 170 & 8.5 & $850(1700)$ & 12.8 \\
\hline$\Delta$ & $5^{\star}$ & 170 & 5.5 & $850(1700)$ & 12.8 \\
\hline - & 1 & 60 & 5.5 & 60 & - \\
\hline$\nabla$ & 1 & 52 & 5.5 & 72 & - \\
\hline
\end{tabular}

* double row, 5 charges each at 40-foot separation

Figure 8. Peak particle motion from row charges scaled (square-root) as a line or cylindrical charge 


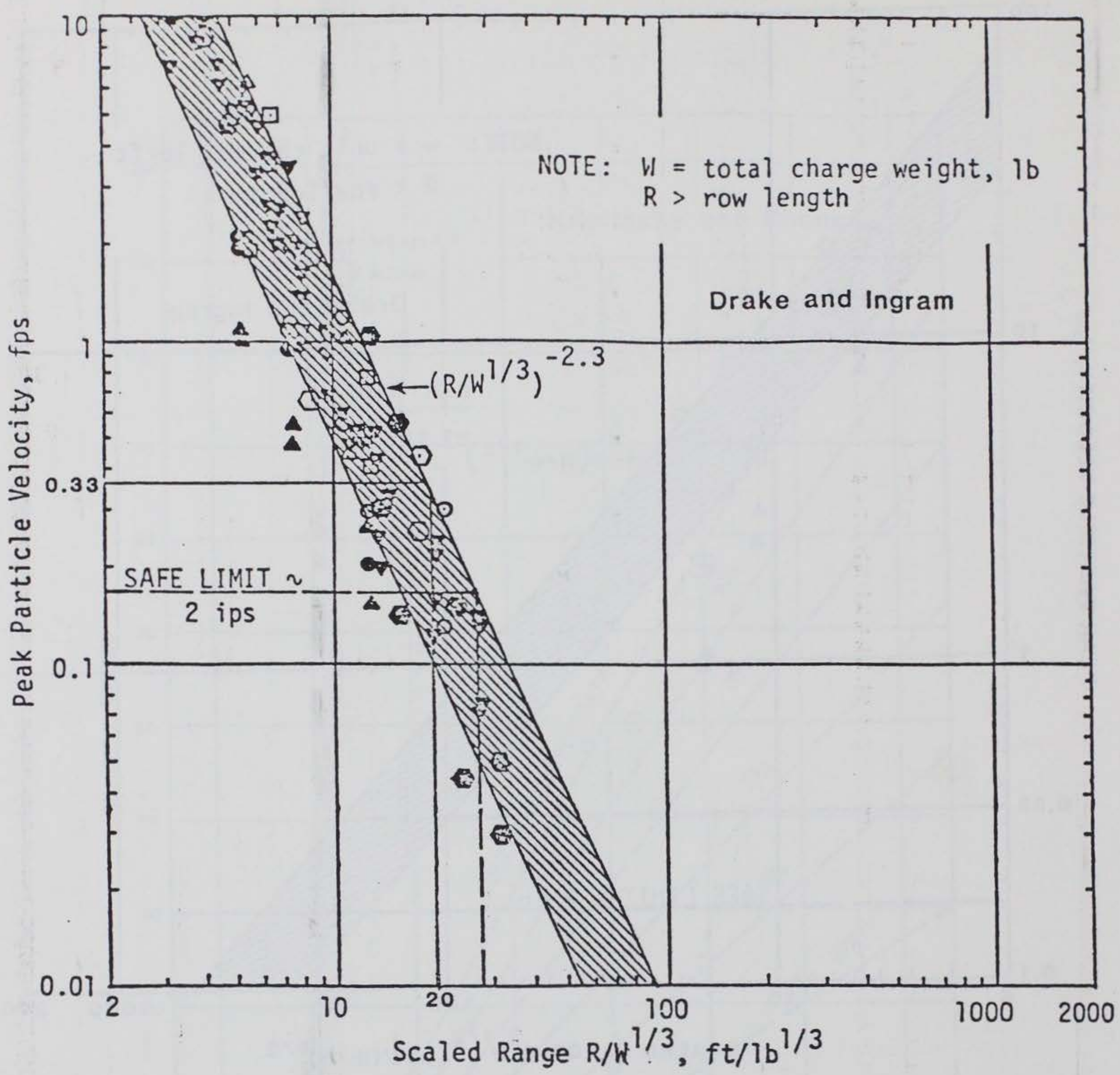

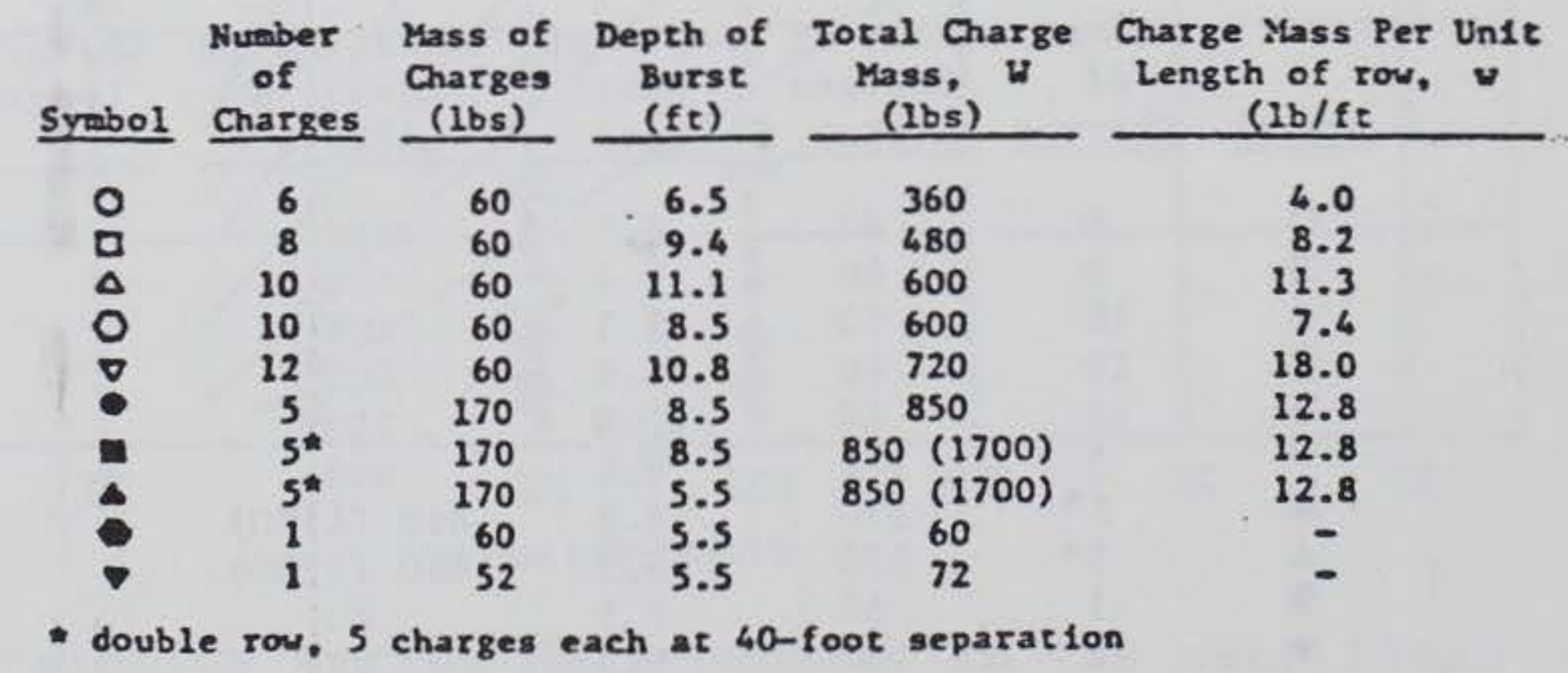

Figure 9. Peak particle motion from buried single and buried row charges 
were measured axially and along the perpendicular bisector to the row. The number of charges varied from 6 to 12 and the spacing and depth of burst were also varied. Linear charge densities varied from 4 to $18 \mathrm{lb} / \mathrm{ft}$.

16. Figures 8 and 9 were compiled by Drake and Ingram (1981). Unfortunately, only a few of the measurements fell within the cylindrical wave region. Peak particle velocity data in the region nearer than the length of the row of the linear charge density. An upper-bound attenuation curve was fitted using a variation of pear particle velocity with scaled range as the -1.15 power. Data within the spherical region are shown in Figure 9, where the peak particle velocity is plotted versus the range scaled to the cube root of the total charge mass. The peak particle velocity varies here as the -2.3 power of the scaled range.

17. From these data plots, one may estimate peak particle velocity as a function of distance from the closest charge. Since the setback levee and Wickliffe, KY, are near the transition point from the cylindrical to the spherical region, it is necessary to apply both geometric cases to them to determine the worst case.

18. Based on Figure 8 (cylindrical shape), a peak particle velocity of $10 \mathrm{~cm} / \mathrm{sec}(0.33 \mathrm{ft} / \mathrm{sec})$ is expected at a scaled range of, at most,

$$
R / W^{1 / 2} \simeq 210 \mathrm{ft} /(1 \mathrm{~b} / \mathrm{ft})^{1 / 2}
$$

where

$$
\mathrm{W}=\text { charge mass per unit length of row, } 1 \mathrm{~b} / \mathrm{ft}
$$

Then for both crevasses, a peak particle velocity of $10 \mathrm{~cm} / \mathrm{sec}$ is not expected to occur beyond a distance of

$$
\mathrm{R}=210 \times(22.7)^{1 / 2} \simeq 1000 \mathrm{ft}
$$

19. A conservative safe distance can also be estimated by considering the spherical shape condition (Figure 9). For this case, crevasse No. 1 would have a scaled range for $10 \mathrm{~cm} / \mathrm{sec}$ of about

$$
R=20 \times(253,000)^{1 / 3} \simeq 1275 \mathrm{ft}
$$


and for crevasse No. 2, it is

$$
R=20 x(136,000)^{1 / 3} \simeq 1030 \mathrm{ft}
$$




\section{Limits of Liquefaction Damage}

20. Reasonable estimates for the maximum distances at which liquefaction might occur from long row cratering charges are summarized as follows:

Parameter

Peak particle velocity

Safety Criterion
$10 \mathrm{~cm} / \mathrm{sec}$
(cylindrical shape)
(cylindrical shape)
(spherical shape)
(spherical shape)

Distance ( $f t)$ from Crevasse

$>1000$ for No. 1
$>1000$ for No. 2
$>1275$ for No. 1
$>1030$ for No. 2

The median values of peak acceleration and duration (where acceleration $\geq 0.05 \mathrm{~g}$ ) for magnitude 5.0 earthquakes are about $0.12 \mathrm{~g}$ and $5 \mathrm{sec}$, respectively.

\section{Effects at Mainline Setback Levee}

21. The minimum distance between any portion of the setback levee and the fuze plug is $9500 \mathrm{ft}$. Since this distance is much greater than the maxirum distance that a peak particle velocity of $10 \mathrm{~cm} / \mathrm{sec}$ will occur $(1275 \mathrm{ft})$, the setback levee is predicted safe from any liquefaction hazard. The peak velocity at the closest section of the levee to the explosive charges is less than $0.08 \mathrm{~cm} / \mathrm{sec}$ (according to Figure 9).

\section{Effects at Wickliffe, KY}

22. Wickliffe, KY, situated at least $8400 \mathrm{ft}$ from the midpoint of crevasse No. 1, is the closest major center of population to the fuze plug sections. As with the setback levee, this distance is much greater than the maximum distance for a peak particle velocity of $10 \mathrm{~cm} / \mathrm{sec}$. The peak particle velocity at $8400 \mathrm{ft}$ should be about $0.1 \mathrm{~cm} / \mathrm{sec}$ (according to Figure 9). In addition to this, Wickliffe is situated on top of a dry loess deposit underlain by Tertiary deposits. Since neither dry loess deposits nor Tertiary deposits are normally susceptible to liquefaction, there is no doubt of the safety of Wickliffe. 


\section{q STATIONS ON FUZE PLUG LEVEE}

295
205

Figure 10. Borehole log profile 
23. Cairo, IL, is located about $17,000 \mathrm{ft}$ northwest of the northern end of the fuze plug No. 1. At this distance, a peak particle velocity of less than $0.03 \mathrm{~cm} / \mathrm{sec}$ (according to Figure 9) can be expected, which indicates no liquefaction potential exists at this site.

\section{Effects on the Fuze Plug Levee}

24. Boring samples taken along the fuze plug section of crevasse No. 1 indicate that sections of the fuze plugs foundation might be susceptible to liquefaction. The scarcity of borings along the fuze plug section make it impossible to draw any definite conclusions. Figure 10 shows the profile of the boring logs taken in the immediate area of the fuze plug section. Layers of silty sands with relatively low blow counts were found as shallow as $26 \mathrm{ft}$ (depth to top of layer) below the center line of the fuze plug levee. The thickness of these layers varied, as shown in Figure 10. Beneath the surficial clays, there were layers of silty sand, sand, sandy gravels, and silty gravels extending all the way to the bottom of the boreholes. All of these layers lie beneath the observed water table (Figure 10). The proximity of these saturated layers to the explosive charges indicates a liquefaction potential.

25. If liquefaction does occur under fuze plug No. 1, it would seem that the hydrostatic pressure on the river side of the levee would result in movement of the fuze plug's remains inland. This would probably increase the rate of water flow into the floodway, which might even be a desirable result. However, if reconstruction plans for the fuze plug levee are designed under the assumption that the original foundation will be intact, this would not be a desirable result. If the foundation of the fuze plug does liquefy, there will most likely be some liquefaction in the foundation of the levee sections located at the ends of the fuze plug also. The result of this would be, in effect, to increase the length of the fuze plug, which would increase the ultimate reconstruction costs. The liquefaction effects could not extend more than about $1000 \mathrm{ft}$ beyond the ends of the explosive line.

26. Boring samples taken along the fuze plug section of crevasse No. 2 indicate that the fuze plugs' foundation is not susceptible to 
liquefaction. A relatively thick overburden of clay (minimum thickness of $65 \mathrm{ft}$ ) lies on top of well consolidated layers of sand and sandy clays.

\section{Conclusions}

27. As a result of this study, the following conclusions were drawn:

a. Structures should be safe from potential liquefaction beyond $1275 \mathrm{ft}$ from fuze plug No. 1.

b. There will be no liquefaction occurring at fuze plug No. 2 .

c. Neither Wickliffe, KY, nor Cairo, IL, are in danger of blast-induced liquefaction.

d. Liquefaction might occur in the foundation of the fuze plug No. 1. If this occurs, the remains of the blown fuze plug's foundation will probably move inland and/or sink slightly. If liquefaction occurs, foundations under the newly exposed end sections of the forward levee at the ends of crevasse No. 1 will probably liquefy. Liquefaction effects could extend to no more than about $1000 \mathrm{ft}$ beyond the ends of the explosive line. 


\section{REFERENCES}

Brazee, R. J. 1930. "Reevaluation of Modified Mercalli Intensity Scale for Earthquakes Using Distance as Determinant," NUREG/CR-1804, US Nuclear Regulatory Commission, Washington, DC.

Drake, James L., and Ingram, Leo F. 1981. "Predictions of the Airblast and Ground Motions Resulting from Explosive Removal of the Bird's PointNew Madrid Fuze Plug Levee," Miscellaneous Paper SL-81-30, US Army Engineer Waterways Experiment Station, CE, Vicksburg, MS.

Krinitzsky, E1lis L., and Chang, Frank K. 1977. "State of the Art for Assessing Earthquake Hazards in the United States," Report 7, "Specifying Peak Motions for Design Earthquakes," Miscellaneous Paper S-73-1, US Army Engineer Waterways Experiment Station, CE, Vicksburg, MS.

Kuribayashi, Euchi, and Tatsuoka, Fumio. 1975. "Liquefaction During Earthquakes in Japan," Soils and Foundations, Vol 15, No. 4, The Japanese Society of Soil Mechanics and Foundation Engineering.

Murre11, D. W. 1977. "Ground Motion Data from Row Charges," unpublished data, US Army Engineer Waterways Experiment Station, CE, Vicksburg, MS .

US Army Engineer District, Memphis. 1979. Emergency Employment of Army Resources, Appendix R to Supplement A to ER 500-1-1, Natural Disasters Procedures under PL 84-99, Operation of Bird's Point-New Madrid Floodway, MDR 500-1-1, Appendix R (draft report).

Youd, T. L. 1977. "Brief Review of Liquefaction During Earthquakes in Japan," Soils and Foundations, Vol 17, No. 1, The Japanese Society of Soil Mechanics and Foundation Engineering. 
APPENDIX A: REVIEW OF CONCLUSIONS

BY

PROFESSOR H. B. SEED 


\section{Al. Bolton Seed, Enc.}

Lt. Stephen G. Sanders, Research Geophysicist

Geophysics Division

U.S. Army Waterways Experiment Station

Corps of Engineers

P. O. Box 631

Vicksburg, MS 39180

Dear Lt. Sanders,

As you requested I have reviewed the report on "Assessment of the Liquefaction Hazards Resulting from Explosive Removal of the Bird's Point-New Madrid Fuze Plug Levee." My review comments are presented on the attached sheets. Following a totally different line of approach I arrive at similar results to those presented in the report and I therefore agree with the overall conclusions of the report.

\section{Sincerely yours,

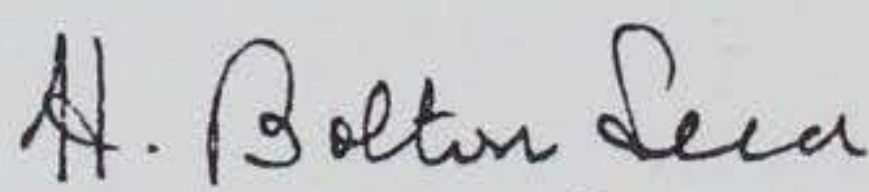

H. Bolton Seed.

$\mathrm{HBS} / \mathrm{nh}$

\section{Enclosures}

CC: A. G. Franklin

W. F. Marcuson III 


\section{H. Bolton Seed \\ Review Comments on WES Report}

ASSESSMENT OF THE LIQUEFACTION HAZARDS RESULTING FROM

EXPLOSIVE REMOVAL OF THE BIRD'S POINT-NEW MADRID

FUZE PLUG LEVEE

This report examines the threshold conditions which could be expected to cause soil liquefaction in the vicinity of a large explosion by using data from observations of soil behavior during earthquakes. The main line of argument used in the report seems to be that:

1. No liquefaction is known to have occurred during earthquakes when the M.M. Intensity at a site is VI or less (essentially this is so by definition since if evidence of liquefaction had been noted the Intensity would have been described as VII).

2. For earthquakes producing Intensity VI, observed data shows a mean value of peak ground velocity of about $10 \mathrm{~cm} / \mathrm{sec}$.

3. Hence if the peak ground velocity produced by an earthquake or an explosion is less than $10 \mathrm{~cm} / \mathrm{sec}$, liquefaction will not occur.

The main limitations of this approach are:

1. The wide scatter of the data relating Intensity with ground motion characteristics. Thus it may be seen from Fig. 7 that Intensity VI is associated with peak ground velocities ranging from 1 to $28 \mathrm{~cm} /$ sec. with many sites showing values less than $10 \mathrm{~cm} / \mathrm{sec}$.

2. The fact that nothing is known about the soil conditions at the sites where Intensity VI was associated with peak velocities exceeding $10 \mathrm{~cm} / \mathrm{sec}$. It could be that the absence of liquefaction at these sites was due to the fact that they were dense sand or clayey soils and has nothing to do with the recorded motion levels. If this were so, then the peak velocity values associated with possibly vulnerable sites would be 1 to $9 \mathrm{~cm} / \mathrm{sec}$ with a median value of $5 \mathrm{~cm} / \mathrm{sec}$. 
3. Using the same arguments as those used to conclude that Intensity VI is not associated with soil liquefaction, one must conclude that sites with Intensity VII do have liquefaction potential and, as shown in Fig. 7, for many such sites velocities as $10 \mathrm{w}$ as 1 to $14 \mathrm{~cm} / \mathrm{sec}$ have been recorded. If liquefaction can occur at these values of peak velocity, the selection of $10 \mathrm{~cm} / \mathrm{sec}$ as a threshold value below which it can not occur seems to require further support.

A second line of argument, which is not clearly spelled out in the report but which can certainly be implied, is the observation, based on field performance, that for earthquakes of Magnitude 5, no liquefaction would be expected to occur at distances greater than $1 \mathrm{~km}$ from the epicenter. The basis for this statement is the data presented in Fig. 3. Considering all of the data (Japanese plus U.S., and especially the liquefaction at Lake Merced in the 1957 San Francisco earthquake) in this figure leads to the conclusion that the earthquake Magnitude for which no liquefaction would be expected to occur would be a Magnitude $4 \frac{1}{2}$ event, which by the reasoning presented in the report, would be associated with an epicentral intensity of $\mathrm{V}$ and thereby with a median peak ground velocity of about $3 \mathrm{~cm} / \mathrm{sec}$.

However it could also be argued that the contemplated explosion releases less energy than a Magnitude $4 \frac{1}{2}$ earthquake and should therefore not cause liquefaction at distances more than $1 \mathrm{~km}$ from the explosion for this reason.

Because of the limitations of the arguments noted above I have consiciered it desirable to explore an alternative approach to establishing a threshold value of peak ground velocity below which the explosion would not be expected to cause liquefaction. This approach is also based on 
the field conditions causing liquefaction in previous earthquakes (see Reference 1) and on the premise that the effects of the explosion would be no more conducive to liquefaction than a Magnitude 5 earthquake. Based on these concepts, an analysis of the threshold conditions for liquefaction can be made as follows:

(1) For silty sands and finer-grained soils

Field data shows that for these types of soil, even in a very loose condition represented, say, by an $\mathrm{N}_{1}$-value (normalized SPT value) of $1 \mathrm{blow} / \mathrm{ft}$, the cyclic stress ratio required to cause liquefaction is about 0.16 for a Magnitude 5 earthquake. Since the cyclic stress ratio is defined as:

$$
\frac{\tau_{\text {av }}}{\sigma_{0}^{\prime}}=0.65 \cdot \frac{a_{\max }}{g} \cdot \frac{\sigma_{o}}{\sigma_{0}^{\prime}} \cdot r_{d}
$$

we can determine the maximum ground acceleration causing liquefaction of such soils by conservatively substituting in the above equation:

$$
r_{\mathrm{d}}=1
$$

and

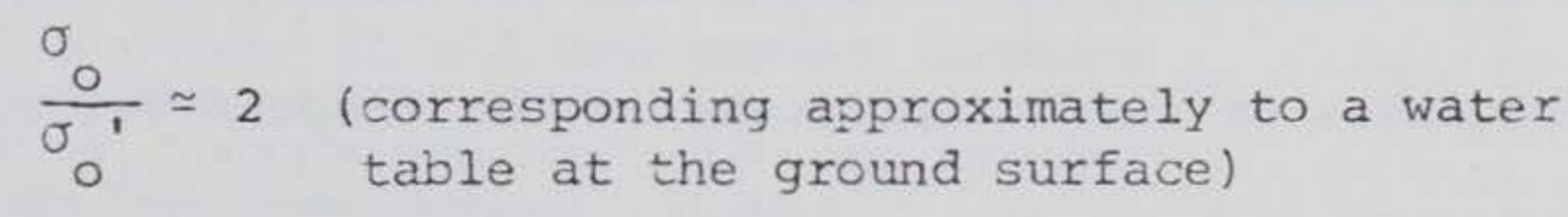

In this case we could determine the threshold value for liquefaction from the equation

$$
\frac{\tau_{\mathrm{av}}}{\sigma_{0}^{\prime}} \simeq 0.16 \simeq 0.65 \frac{\left(\mathrm{a}_{\max }\right) \mathrm{h}}{\mathrm{g}} \cdot 2
$$

leading to $\left(\mathrm{a}_{\max }\right)_{\text {th }} \simeq 0.125 \mathrm{~g}$.

Since analysis of earthquake motions has shown that for soil deposits,

$$
\frac{v_{\text {max }}}{a_{\text {max }}} \simeq 120 \mathrm{~cm} / \mathrm{sec} / \mathrm{g}
$$

the corresponding value of threshold velocity would be 


$$
\left(v_{\max }\right)_{\text {thi }} \simeq 0.125 \times 120 \simeq 15 \mathrm{~cm} / \mathrm{sec} \text {. }
$$

It can be concluded therefore that very loose silty sands or finer grained soils are not likely to liquefy for velocities lower than $15 \mathrm{~cm} / \mathrm{sec}$.

\section{(2) For clean sands}

For clean sands, the vulnerability to liquefaction is greatly influenced by the density of the sand. However, very few deposits have a relative density less than, say, 30 percent, and for this relative density, the in-situ normalized penetration resistance would be about 4 . If we consider this as the poorest soil condition likely to exist in the vicinity of the explosion, then considering the explosion to be equivalent to a Magnitude 5 earthquake would lead to the conclusion, based on field liquefaction data, that the threshold value for stress ratio would be 0.09 (see Reference 1 ).

Using the same procedure as for silty sands, this can be shown to correspond to a threshold value of peak velocity of

$$
\left(v_{\max }\right)_{t h} \simeq 8.5 \mathrm{~cm} / \mathrm{sec} \text {. }
$$

This means that even very loose sands are not likely to liquefy in liagnitude 5 earthquakes or large explosions if the induced velocity is less than $8.5 \mathrm{~cm} / \mathrm{sec}$.

Based on the above and the data in the report, I conclude that the threshold value of peak ground velocity of about $10 \mathrm{~cm} / \mathrm{sec}$ used to evaluate liquefaction susceptibility in this study report is reasonable, and accordingly, that the main conclusions of the report are justifiable and appropriately consistent with the present state of knowledge of vibration-induced liquefaction phenomena.

\section{$\underline{\text { Reference }}$}

1. Seed, H. Bolton and Idriss, I. M., "Evaluation of Liquefaction Potential of Sand Deposits Based on Observations of Performance in Previous Earthquakes," ASCE Conference, St. Louis, MO, October, 1981. 